\title{
Chapter 7 \\ Industrial Policy and InTellectual Property in JAPAN AND BEYOND
}

\author{
CHRISTOPHER HEATH
}

At the end of the twentieth century, a good part of the Asian continent seemed to have lost confidence in itself. 'Asian values' were not only sceptically discussed in the US and European circles, but also within Asia itself. $^{1}$ Even earlier, the limits of Japan's formula of success as one based on bureaucratic intervention were meticulously exposed. ${ }^{2}$ While it would be wrong to try to insulate one single factor responsible for the success or failure of industrial development, the system of intellectual property rights or the absence of such - should not be underestimated, particularly when analysing the Japanese experience.

\section{THE CASE OF JAPAN}

Development of Intellectual Property

Being a country of sparse national resources, Japan had to rely on entrepreneurial ingeniousness and the promotion of inventive efforts through intellectual property rights. ${ }^{3}$ Turning to intellectual property rights to achieve its goals of 'fukoku kyôhei' (a rich country and a strong army) and 'shokusan kôgyô' (increase industrial productivity) was by no means a foregone conclusion for the Meiji state. After all, in 1721 the military Tokugawa regime that ruled the country between 1603 and 1868 had proclaimed a law that prohibited technical innovations. ${ }^{4}$ Nevertheless, patent systems that the Japanese had seen operating in the United Kingdom, the United States, and France, were soon identified as the motor of industrial development. During a visit to the US Patent Office around the turn of the century the first President of the Japanese Patent Office, Korekiyo Takahashi, reportedly stated:

We have looked about us to see what nations are the greatest, so that we can be like them. We said: 'What is it that makes the United States such a great nation?,' and we investigated and we found that it was 


\section{CHRISTOPHER HEATH}

patents, and so we will have patents (US Department of Commerce/Patent Office 1972:20).

Yet the first Japanese patent law, the Sembai ryaku kisoku, enacted in 1871, had to be scrapped when after one year not a single patent application had been made. Just as well, since there would not have been any properly trained examiners for examining patents:

If someone requests a patent for a supposedly new invention, it is extremely difficult to determine to what extent the invention is really new. In order to conduct a thorough examination, one would have to employ 50 foreigners. In employing 50 foreigners, it would be necessary to employ the same number of translators. This is certainly very expensive. But were there really so many inventions? The only invention that people talked about in these days was the invention of the rickshaw (Tsûsanshô (Ministry of Trade and Industry) 1964:558).

Undeterred, the subsequent Patent Monopoly Ordinance (Sembai tokkyo jôrei) was promulgated on 18 April 1885, and was revised in 1888, 1899, and 1909. Only in 1921 and upon the introduction of the first-to-file system had Japanese patent law found a structure similar to that of the Patent Act of 1959, which is still in force today.

So important was the post of President of the Patent Office that Korekiyo Takahashi ${ }^{5}$ later on became Minister of Finance and for a couple of months even Prime Minister. In 1885, in the first year of its existence, 425 applications were filed under the new Patent Act, of which 99 were granted. Already in the following year, the number of applications had doubled to 1,384, while 205 patents were granted (Tokkyo Kyoku (Patent Office) 1934:59). In 1900, for the first time the number of patent applications exceeded 2,000 (actually 2,006). In 1920, the 10,000 mark was surpassed $(11,017)$; in 1966, the number for the first time exceeded $50,000(55,970)$; in 1972 , the 100,000 mark was passed $(102,948)$; and in 1993, a peak was reached with 361,985 patent applications. ${ }^{6}$

An example of successful legislation complying with the domestic needs of a still fledgling industry was the introduction of a utility model system in 1905. After the accession to the Paris Convention, it had become clear that only foreigners were filing inventions that were novel worldwide. Japanese inventive activity, on the other hand, was seriously hampered by the fact that no special protection could be sought for minor improvements. Competitors were keen to imitate any such improvements, with the result that the quality of goods often deteriorated. Thus, the first Utility Model Act (also termed Petty Patent Act, or Sub-Patent Act, depending on the legal 
system) of 1905 allowed exclusive rights over 'useful developments concerning the shape, arrangement or concept of a commercial object.' With a protection period of six years and the novelty requirement limited to Japan, the Act satisfied domestic needs for short-term, low-level protection without choking the patent register with long-term monopolistic rights over minor improvements. According to statistics, the utility model system has been a success. Unlike patents, utility models never appealed much to foreigners, and over the years less than two per cent of the applications came from abroad. In Japan, the number of filings rose from 2,011 in 1906 to more than 180,000 in 1980 . Only by the late 1980 s, had the number of patent applications exceeded the number of utility model applications. This in turn led to a significant change in the utility model system in 1994 (Law No 116, 1994). Since utility model protection had apparently outlived its purpose of serving domestic industry, the term of protection was shortened and rights granted without examination. However, examination is still necessary before raising an infringement suit. In effect, the changes have been the death knell of the utility model system (Tamai, 1992), as is also indicated by the application figures which dropped by more than 80 per cent.

The exact application figures are as follows:

\begin{tabular}{|c|c|c|}
\hline Year & Application & Granted \\
\hline 1906 & 2,011 & 985 \\
\hline 1910 & 14,057 & 4,358 \\
\hline 1920 & 18,543 & 3,584 \\
\hline 1930 & 33,111 & 12,060 \\
\hline 1940 & 30,105 & 16,535 \\
\hline 1950 & 22,426 & 6,365 \\
\hline 1960 & 68,102 & 18,208 \\
\hline 1970 & 124,170 & 29,264 \\
\hline 1980 & 185,455 & 44,600 \\
\hline 1990 & 138,294 & 43,300 \\
\hline 1993 & 77,101 & 53,400 \\
\hline 1995 & 14,886 & 63,966 \\
\hline
\end{tabular}

No less interesting is the gradual expansion of patentable subject matter. Only in 1975 was patent protection for pharmaceutical substances introduced; as of 1979, micro-organisms were deemed patentable; during the 1980 s, resistance against granting patents for genetically engineered 
products was overcome; and in 1988, the first patent for animals was applied. In 1997, new guidelines of the Patent Office were issued to facilitate the patenting of computer software and biotechnology.

\section{Rules on Technology Transfer}

Apart from legal structures, Japan advanced and refined its system of IP rights by institutional structures and administrative competencies. From the start the Patent Office, and thereby the responsibility for preparing legislation in the field of IP rights, fell into the competency of the Ministry of Agriculture and Trade. Subsequently it was the famous or infamous Ministry of Trade and Industry (MITI), rather than the Ministry of Justice that was responsible for preparing legislation in the field of civil law in general.

Institutional control of intellectual property policy has been particularly important for Japan in the field of international technology transfer. The institutionally responsible Fair Trade Commission (FTC) published its first Guidelines on International Licensing Contracts in 1968 , and subsequently revised them in 1989 (Iyori and Uesugi, 1994:467) and 1998. 'Until 1992, all international contracts had to be notified, and until 1997 the notification requirement continued for exclusive licenses only. ${ }^{10}$ The FTC was particularly concerned with so-called grant-back clauses, whereby licensees were obliged to transfer improvement inventions to the licensor without proper remuneration."

Both the FTC and the courts have done much to encourage the so-called parallel importation of foreign made goods in order to lower the price level of imports. $^{\text {I2 }}$

\section{Inherent Weakness of Enforcement}

According to a survey conducted in 1996, Japan is not a popular place for initiating patent infringement suits. It is placed among the last five countries, along with Italy, Spain, Argentina, and India. Even Indonesia and Brazil enjoyed a better reputation than Japan (The World Patent Survey, 1996:19 (20)). Several reasons have been made responsible for this outcome:

1. Due to a very narrow interpretation of the function of the judiciary, very seldom do judges engage in what would be called 'social engineering' in order to solve a case. Rather it is viewed as the task of bureaucratic administration to balance conflicting interests before proposing legislation the abstract, ex ante control is favoured over the ex post control. ${ }^{13}$ It is thus no coincidence that court decisions discuss the facts of a case very broadly, but attach much less importance to their legal deductions (Rahn 1990:321ff). 
2. Access to training for the legal profession is severely limited, thus creating a shortage of attorneys and judges (Henderson, 1997:27).

3. Due to the lack of specialized courts in matters of intellectual property and the frequent transfer of judges, interpretation tends to stick to the letter of the law due to inexperience and uncertainty. And again, granting protection beyond the letter of the law would mean upsetting the industrial policy the law-making bureaucracy had in mind.

\section{Fuzzy Logic and International Obligations}

Japan joined the Paris Convention in 1900. Despite pressure from foreign nations, particularly France and the United States, Japan at first did not give foreigners access to its intellectual property system. Japan was well aware that investment would flow into Japan nevertheless. ${ }^{14}$ Japan thus used the accession to the Paris Convention as a bargaining tool in revising the socalled 'unequal treaties' the Shogunate had entered into with several Western powers (Russia, the United States, France, and the United Kingdom) in 1858. This exempted foreigners from these nations from the allegedly 'barbaric' Japanese jurisdiction (Rahn, 1983:461). Only upon a revision of the unequal treaties did Japan join the Paris and Berne Conventions. However, Japan refused to join the Madrid Arrangement for the Repression of False or Deceptive Indications of Source on Goods concluded in 1891, despite repeated requests from the French Government to do so, for the following reasons:

Most Japanese exports go to countries that have not joined the Agreement, while on the other hand misleading indications of origin from member countries are rare. The main export markets of Japan, that is China, the US, and Germany (the latter being the country where most misleading indications of origin have become known, particularly earthenware from China), have not yet joined the Agreement. Japanese industry is still at the stage of copying and imitation. The average domestic consumer prefers foreign goods, for which reason a number of domestic producers label their goods misleadingly as foreign. Japanese industry is still in its infancy and has little experience of exporting, so confidence in its products is low and it is very difficult to find markets for goods labelled as 'Made in Japan'; therefore, misleading indications of origin are not infrequent. For these reasons, to join the Arrangement would be of very little practical use for promoting [the] Japanese economy. On the contrary, it would rather be an impediment. ${ }^{15}$ 
Only upon the conclusion of the San Francisco Peace Treaty in 1952, was Japan obliged to ratify the Madrid Arrangement.

Given this historical background, it is quite obvious that Japan had joined the Paris Convention for political and economic reasons, rather than for the conviction that 'the inalienable right of the inventor should be protected by the laws of all cultured nations,' as was the driving idea behind the Paris Convention (Ladas, 1930:74). Rather, Japan has always taken the view that 'unlike fundamental human rights, intellectual property rights are not inherent; rather, they are granted in line with certain policy objectives, such as the promotion of industrial development and the stimulation of cultural activities. Because of this, current intellectual property rights protection systems are not absolute in nature; they change as the policy objectives change. However, the present system is based on granting proprietary rights over intellectual property. ${ }^{, 16}$

The first unwelcome obligation under the Paris Convention came in 1925, when under the Hague Revision Conference all Member States were obliged to enact measures against unfair competition. ${ }^{17}$ Japan was thus put in a quandary because it had always tolerated acts of unfair competition, particularly the copying of foreign goods and piracy applications of foreign trademarks, because these practices were considered to be advantageous to Japanese industry (Tokkyo Chô (Patent Office) 1955:101). When Japan finally appeared to comply with Art. $10^{\text {bis }}$ Paris Convention by enacting an Unfair Competition Act in $1934,{ }^{18}$ the Act proved inapplicable due to the requirement of intentional contravention against fair competition. In addition, one provision exempted acts under registered industrial property rights - most likely a provision to protect trademark pirates. ${ }^{19}$

Until 1950, only one reported case under the Unfair Competition Act went up to the Supreme Court. ${ }^{20}$ Japan had thereby found the perfect fuzzy logic formula by enacting laws to avoid foreign sanctions, but declining to apply the law in order to avoid unwelcome results at home (Rahn and Heath, 1994:345). Regarding trademark piracy in particular, Japan was very much against the adoption of Art. $6^{\text {septies }}$ Paris Convention (misappropriation of a trademark by an agent or representative) at the Lisbon Revision Conference in $1958 .^{21}$ With regard to piracy applications of trademarks, a Japanese court as late as 1989 held that 'deft use of another's achievements without compensation cannot normally be considered unlawful. ${ }^{, 2}$ Part of the relative ease with which trademark pirates have been able to avoid persecution in Japan is the apparent incompetence of Japanese courts to recognize bad faith where it so obviously exists. In the above-quoted 'Popeye' case, a Japanese party in 1965 had registered a mark almost identical with the Popeye drawings from Chrysler-Seager. Despite this fact, 
even the Supreme Court did not find this was a misappropriation in bad faith. ${ }^{23}$

Another contentious issue has always been the proper remuneration particularly of foreign owners of copyright and neighbouring rights in Japan. Although a member to the Berne Convention as early as $1899,{ }^{24}$ collection of user fees did not begin until the mid-1930s. This was when a German lawyer was requested by several collecting societies, both from the US and Europe, to enforce Japan's copyright provisions with respect to foreign musical works such as Ravel's Bolero or the works of Puccini. ${ }^{25}$ More recently, Japan was brought before the WTO, because she had refused retroactive protection of neighbouring rights for phonogram producers. ${ }^{26}$ The issue has now been settled due to a change in Japanese legislation. ${ }^{27}$

\section{ASIA BEYOND JAPAN ${ }^{28}$}

\section{Using Japan as a Blueprint: Korea}

The intellectual property system of Korea is closest to the Japanese not merely because of geographical proximity, but also because of Japanese colonisation between 1908 and 1945. Bureaucratic structures were either left in place or else adopted from a country whose language was fairly familiar to those shaping the country after the devastating Korean War in 1953. As in Japan, the Ministry of Trade and Industry (MITI, now METI) is responsible for shaping not only industrial policy, but also industrial property. On the legal side, the Korean Unfair Competition Act is little different from the one the Japanese enacted for Korea in 1935. Also other industrial property laws have been closely modelled after those of Japan. ${ }^{29}$

However there are two aspects which distinguish Korean industrial policy from the Japanese. Korea had much less time to develop structures which were not in accordance with international obligations due to increasing pressure from industrialized countries to grant proper protection. A typical example might be the so-called pipeline protection for pharmaceuticals that was first granted to the US and subsequently to European applicants. ${ }^{30}$

In addition, due to a more litigious legal culture in Korea, the Supreme Court is far more active and assertive in its ruling than its Japanese counterpart. In one decision in 1995, the Korean Supreme Court ruled it unconstitutional that there were no proper channels to appeal decisions of the Patent Office. ${ }^{31}$ This led to setting up a Patent Court (by the Law of 14 July 1994), which took up its work on 1 March 1998. 


\section{Mighty Mandarins: China, Taiwan, and Singapore}

The above parameters of the Japanese model of success - viewing intellectual property protection as a chance for the development for domestic industry, while trying to give only limited domination to foreign right owners - have also been adopted in countries whose bureaucratic mandarins were savvy enough to see not only the downside but also the merits of intellectual property rights. Particularly in China, three attributes of the Japanese system, that is, setting up an intellectual property system for the sake of domestic industrial development, preference of bureaucratic institutions over independent courts, and an institutionalized weakness of enforcement, can also be detected:

As usual, enforcement is not so much a matter of law as of will. At the top, Chinese leaders understand that the country must protect intellectual property rights if it hopes to attract foreign technology and develop its own industry. But enforcement is complicated by what we call the rule of law with Chinese characteristics: Who is going to order the police on raids for the police report to the guilty parties? The interests of the various laws read: 'In These Pirate Firms Further Explain the Lack of Enforcement Here.' We would note however, that China knows how to enforce the law when it wants. Last year, Reebok worked with the Chinese administration for industry and commerce, leading to raids of 45 factories, the confiscation of some 120,000 pairs of counterfeit shoes. China has officially urged consumers to boycott pirated disks and books, the software and entertainment industry losing some 900 million dollars each year to Chinese piracy where demand requires to go after suppliers. ... Finally while the world can do only so much to change China's behaviour, it cannot least maintain the standards of groups like the World Trade Organisation, a powerful reminder to China that while membership has its privileges, it also has its responsibilities. ${ }^{32}$

From 1985, China put enormous efforts into developing an intellectual property system. Apart from having processed 400,000 applications for patents and designs, the Chinese Patent Office amassed 30 million patent documents from twenty different countries in the first ten years of its existence. At the end of 1993, about 400,000 trademarks have been registered in China, while there were about 5,000 qualified patent attorneys.

It comes as no surprise that compliance with international obligations has not been China's first priority: practicing lawyers, for example, complain about unrealistically short deadlines for responses particularly under the Madrid Agreement for the Protection of Trade Marks. 
While Taiwan overhauled her intellectual property system between 1992 and 1996, a similar preference for administrative enforcement and lack of proper judicial control can be found. Taiwan and China, and to a lesser degree Hong Kong, are the main offenders when it comes to the application of piracy trademarks, either domestically or in other Asian countries.

Due to the fact that registering patents in the United Kingdom was unattractive to domestic industry, Singapore revamped much of its industrial property system in 1995. Not unlike Japan, Singapore has attached much importance to promoting industrial development through allowing parallel imports.

\section{Intellectual Property is Theft: The Case of Developing Asia}

Other countries in the Asian region have viewed intellectual property rights rather as a tool of industrialized countries to dominate their economy (Adelman and Baldia, 1996; Konan et al., 1995:9-12, 13). Opposition against any sort of intellectual property protection has been particularly strong in the most populous Asian countries, such as India and Indonesia.(Antons, 2000; Kaehlig, 1993) The negative approach might have prevented foreign right owners from exploiting their intellectual property rights in general, but has not assisted in developing the certainly vast potential of domestic industry. It may not be completely far-fetched to argue that the ruling classes in these countries have had little interest in upsetting a status quo that was quite favourable to their economic interests. In Indonesia, India, Brazil and a number of African countries, an oligarchy of a few influential families is in many cases primarily interested in perpetuating the structures for political power and self-enrichment.

\section{The Legacy of Colonialism}

The former colonial powers, Great Britain and France, dominated different countries in the Asian region. Britannia ruled the waves and valleys of Malaysia, Singapore, Brunei, and India, while the French colonized Vietnam, ${ }^{33}$ Laos, and Cambodia. Thailand, ${ }^{34}$ through clever diplomacy, remained the uncolonized buffer country between these two. Indonesia was the most important colony of the dwindling Dutch Empire, while the Philippines rid themselves of centuries of Spanish mismanagement in 1898, only to be colonized by the Americans until 1946 (Hooker, 1988). The Japanese occupied Korea, Taiwan, and parts of China, not particularly to these countries' liking.

Colonization had more influence on legal than on religious structures. In many cases, this led to imported legal systems, which clashed with traditional social or religious beliefs. This phenomenon can also be detected 
in countries that remained uncolonized. Japan and Thailand adopted western legal systems that were ill fitted to their cultural beliefs.

Due to colonization, most Asian countries had no choice when introducing intellectual property rights, as their colonial masters dictated the decision. This was more the case in some countries than in others. While Indonesia was particularly fervent in cutting all links to the legal system of her previous masters, the common law countries of Asia not only retained the system, but even accepted - and in some cases still accept - filings effected in London and having validity in their respective countries. The last remnant of this system is the system of design protection in Malaysia that was governed by 1949 British legislation on that subject until September 1999.

\section{The Remains of Communism}

In China and Vietnam, the traditions of intellectual property protection, if any, were discontinued by the advent of Communism. Re-introduction of intellectual property systems that only followed principles of private property and international dialogue had been re-established at the beginning of the 1980s. China joined the WIPO in 1980 and introduced legislation to protect intellectual property rights between 1984 and 1990. Vietnam introduced the first legislation for patent protection in 1981, for trademarks in 1982, and for copyrights in 1986.

\section{WTO/TRIPs - Lead Vest or Silk Gown?}

Quite significant numbers of academics view the WTO/TRIPs Agreement as an act of American Imperialism 'overwhelmingly likely to re-instate and perpetuate dependence. ${ }^{35}$ The way the Agreement was rammed through despite fierce opposition from developing countries certainly smacks of imperialism. What is often overlooked, however, are the chances for developing countries to enact a system of intellectual property protection and technology transfer control that serves as an encouragement to domestic industry as well. With due brevity, the following means can be mentioned:

1. enhancing protection of natural and indigenous resources;

2. introducing a utility model system to encourage small and medium-sized enterprises;

3. narrowing interpretation of patent claims so as to enhance legal certainty and prevent the development of improvements;

4. joining international conventions for the particular purpose of reducing the workload of domestic patent offices. The PCT may be cited as the foremost example in the field of patents;

5. increasing awareness as to the professional training of patent attorneys; 
6. preventing abuse of intellectual property rights by, e.g., permitting the so-called parallel importation of patented and trademarked products and a tight control of clauses detrimental to technical progress, particularly the limitation of the licensee's freedom to develop improvements.

It would be a pity if the chances the WTO/TRIPs Agreement offers to developing countries is lost due to ignorance or neglect on the side of developing countries and undue pressure from the side of the developed countries, particularly the United States.

There are some developments in the right direction, however. The enhanced protection of natural and indigenous resources, deserving particular mention is the Philippine Act No. 8371 of 28 July 1997, that is meant to 'recognize, protect and promote the rights of indigenous cultural communities/indigenous peoples.' A Plant Variety Protection Act, that includes protection for 'local indigenous plant varieties,' 'common indigenous plant varieties,' 'wild plant varieties,' and any sort of 'genetic material,' was promulgated in Thailand in 2000.

As to a utility model system, after a good deal of deliberation, Thailand with its Patent Amendment Act of 27 March 1999 (enforced since 27 September 1999), introduced a petty patent system in Sec. $65^{\text {bis }}-65^{\text {decem }}$ Patent Act. While this is a step in the right direction, Thailand still lacks a proper curriculum for technically trained patent attorneys, a problem that it shares with many other countries in the region.

\section{Intellectual Property as Power to the People}

Proper introduction and enforcement of intellectual property rights may also offer opportunity beyond the sphere of industrial development. It may even be a catalyst for social change. As has been mentioned above, reluctance to introduce intellectual property protection in developing countries was often rooted in patterns of power sharing in oligarchic societies. In many Asian countries democratic shortcomings were seen as a trade-off to fast industrial development and sold as 'Asian values.'

When the economic crisis hit Thailand, its first victim back in July [1997], it was possible for South East Asia's authoritarians to argue that Democracy was part of the problem. They could claim that those Asian countries with short-lived, unstable governments were ill equipped to cope with a crisis and to impose the harsh measures needed to end it. Six months later, the opposite appears to be true: the more democratic countries seem to have the best chance of successful economic reform'(The Economist 17 Jan 1998). The grand old man of legal anthropology, Wolfgang Fikentscher, has convincingly 
argued that the advent of intellectual property rights may well spearhead the consciousness for subjective, human rights in general. Intellectual property rights from a tool of industrial policy to a catalyst for human rights awareness - Asia comes full circle to the driving motives for drafting the Paris Convention in 1883.

\section{NOTES}

1 Periodicals were ripe with titles such as 'Are Asian Values Finished?' as discussed in Far Eastern Economic Review, 22 January 1998, p. 32. More to the point, The Economist, 17 January 1998, p. 58 could write: 'Indonesia is an extreme case of a phenomenon seen in several Asian countries, where a government derives its legitimacy from its ability to deliver economic success rather than from a truly Democratic mandate... "Asian values" were alleged to place greater weight on social order and deference to authority than did values of the decadent western variety.'

2 Particularly in Baum (ed.) 1997.

3 The emergence of the Zaibatsu-Groups from the 1880s onwards owes less to governmental patronage than to tough competition, hard work and commercial astuteness: Hidemasu Morikawa, 1992, pp. 1-55.

4 Shinkihatto no ofuregaki (Ordinance Prohibiting Innovations), Ordinance of the Military Government of July 1721, reprinted in Tokkyo Chô (Patent Office), 1955, p. 36.

5 On Takahashi, see Etsuji Kotani, [1979]. An interesting insight into the exchange between the American and Japanese Patent Office is also given by the exchange of letters between Korekiyo Takahashi and Schuyler Duryee, as reprinted by Kazuto Sakamoto [1989].

6 Figures by Tokkyo Chô, 1955, p. 134, Tokkyo Chô, 1985, p. 756, and Tokkyo Chô, 1995, p. 345.

7 Jitsuyo Shin'anhô as of 15 March 1905, Law No. 21. An analysis is provided by Nobuo Monya, 1973, p. 159.

8 Reprinted in English in Nakagawa, 1984, p. 124.

9 The 1998 Guidelines can be found in English at the FTC's homepage, http://www.jftc.go.jp.

10 The changes were mostly due to US pressure.

11 According to Iyori/Uesugi (p. 305), about 20 per cent of all contraventions concerned grant-back clauses. The concern is understandable insofar as such improvement inventions were the forte of Japanese industry (see above). About one fifth of all contracts were found faulty by the FTC. 
12 The courts have allowed parallel importation of trade marked goods as early as 1970: Osaka District Court, 27 February 1970, 2 IIC 325 [1971] - 'Parker'; the parallel importation of copyrighted goods is permissible unless the copyrighted work enjoys special distribution rights: Tokyo District Court, 1st July 1995, 27 IIC 570 [1996] - 'Beauty and the Beast.' The importation of patented goods is permissible unless notice of the contrary has been given by the patentee: Supreme Court, 1 July 1997, 29 IIC 331 [1998] - 'BBS Car Wheels III.' The FTC has repeatedly taken action against attempts to prevent lawful parallel imports by warning sole import distributors of: Old Scotch Whiskey, Apple Computers and Feinberg Airguns.

13 This has basically been the view in the presentations in Baum, 1997, and in particular: Kono, ibid, p. 69.

14 The connection between foreign investment and intellectual property protection may have been overstated for political reasons. As the Economist, 22 January 1994, 62/63 could write in an article: Intellectual Property is Theft: "In the past, multinationals have invested heavily in countries long before their secrets were safe there. Investment decisions will continue to have more to do with national laws on ownership, market size, and the state of domestic industry than with intellectual property protection.' This, of course, is not what multinationals, particularly pharmaceutical companies, would be keen to admit.

15 This reply is reprinted in Tokkyo Chô, 1955, p. 103-4.

16 Commission on intellectual property rights in the 21 st century, Towards the area of intellectual creation - challenges for break-through, Tokyo released on 7 April 1997, both in Japanese and English.

17 Actes de la Haye, Den Haag 1925, p. 475: Attempts by the French government to agree to an even more forceful wording of the provision of Article 10bis Paris Convention were rejected particularly by Japan.

18 Law No. 14 of 27 March 1934, in force since 1 January 1935.

19 Joseph Koe Toyosaki, [1971]. Already Yoshinobu Someno, [1959] voiced doubt about the use of this provision. Particularly foreign brand names and brand goods were clad with the image of high class also because of the high tax duties levied on them. It is fair to say, however, that in most cases the application of the provision was rejected as an 'abuse of rights.'

20 Decision of 27 August 1942, 14 Tokkyo Kenkyû 24 [1992].

21 See, e.g., Stephan Ladas, 1975, II, p. 1264.

22 Osaka High Court, quoted and overturned by the Supreme Court, 20 June 1990, 25 IIC 118 (129) [1994] - 'Popeye Scarves III.'

23 Supreme Court, decision of 20 June 1990, 25 IIC 118 [1994] - 'Popeye Scarves III.' 


\section{CHRISTOPHER HEATH}

24 Incorporated into the Copyright Act of 4 March 1899, Law No. 39.

25 Dr Wilhelm Plage (1888-1969), who forced particularly Japanese radio stations to pay-up adequate fees, threatening to sue otherwise. Plage (very aptly, the German name means plague) was such a pain in the neck for the Ministry of Culture that it swiftly amended its laws to exempt a number of establishments from payments, and later on helped to establish a Japanese Collecting Society in order to outlaw Dr Plage's activitites. For details, see Shigeo Ooie, 1981.

26 The matter was of particular economic significance to Japan because of the high number of foreign phonograms circulated. The discussion centred around the interpretation of Art. 18(3) Berne Convention, that according to Japanese interpretation left the question of retro-activity to national legislation. A similar stance had been taken by the US upon accession to the Berne Convention in 1988 and more recently by Russia in 1994. For details see, Christopher Heath, 1996, p. 677.

27 By Law No. 117/1996 (26 December 1996), the supplementary provisions of the Copyright Act dealing with retro-active protection were amended. Protection now extends retro-actively to the last 50 years insofar as such protection had not already expired under the old Copyright Act (before 1970). However, the amendment does not permit claims for user fees for phonograms sold hitherto, or for phonograms already produced.

28 Brief overviews are provided by Christoph Antons, [1995] and Michael Blakeney, 1996, p. 544. The following books can be mentioned:

Wineburg (ed.), Intellectual Property Protection in Asia, Butterworth 1991 et seq., loose-leaf. The volume contains a brief general introduction and country reports on China, Hong Kong, Japan, Korea, Malaysia, Singapore, Taiwan, and Thailand.

Institute of Intellectual Property (ed.), Asia shokoku ni okeru chiteki zaisan hogo (Intellectual Property Rights in Different Asian Countries), Tokyo 1995. The work contains a number of useful tables and offers brief country reports (in Japanese) on China, Korea, Taiwan, Hong Kong, Thailand, Indonesia, the Philippines, Malaysia, Singapore, India, and Vietnam.

Asia Law (ed.), 1996 Intellectual Property Protection in Asia Practical Strategies. The book is a compendium on intellectual property in China, Hong Kong, Indonesia, Korea, Malaysia, the Philippines, Singapore, Taiwan, Thailand, Vietnam, Cambodia, and Laos.

Gutterman/Brown (ed.), Intellectual Property Laws of East Asia, Hong Kong/Singapore 1997. General introduction on IP rights in general, and particular country reports on Cambodia, Hong Kong, Indonesia, 
Malaysia, China, the Philippines, Singapore, South Korea, Taiwan, Thailand and Vietnam.

UCLA Pacific Basin Law Journal, Special Issue: Intellectual Property in East Asia, Fall 1994, Vol. 13/1. Aspects of IP protection in Japan, Taiwan, Korea, and China.

International Review of Industrial Property and Copyright Law (IIC), Intellectual Property Rights in Asia, June 1997, Vol. 28/3. Articles and court cases on Malaysia, Indonesia, China, Korea, and Japan.

International Review of Industrial Property and Copyright Law (IIC), Intellectual Property Rights in Asia II, June 1999, Vol. 30/4. Articles and court cases on Thailand, Taiwan, Korea, Vietnam, and Japan.

29 Another example would be the Utility Model Act that is basically an import from Japan and that in 1998 was revised similar to the Japanese Utility Model Act in 1994.

30 Basic agreement with the United States as of 28 August 1986, and a subsequent list of products that should receive the benefit of such protection as of 28 February 1990 (US) and 27 September 1991 (EC).

31 Korean Supreme Court, decision of 28 September 1995, No. 92 Hunga 11.

32 Pirates Kidnap Walt Disney, Far Eastern Economic Review of 19 January 1995, p. 5.

33 For an overview over the intellectual system of Vietnam, see Heath, [1999].

34 For new intellectual property developments in Thailand, see Ariyanuntaka, [1999].

35 McGrath, 1996 and in similar fashion: Oddi, 1987 and 1996, and many others.

\section{REFERENCES}

Adelman, Martin and Sonia Baldia (1996) 'Prospects and Limits of the Patent Provision and the TRIPs Agreement: The Case of India,' Vanderbilt Journal of Transnational Law 507.

Antons, Christoph (1995) 'Analysing Asian Law,' Law in Context 13/1, p. 106.

- (2000) Intellectual Property Law In Indonesia. London: Kluwer Law International.

Ariyanuntaka, Vichai (1999) 'TRIPs and the Specialised Intellectual Property Court in Thailand,' IIC 30, p. 360.

Asia Law (ed.) (1996) Intellectual Property Protection in China-Practical Strategies. Hong Kong. 
Asia Law (ed.) (1996) Intellectual Property Protection in China - The Law, Hong Kong.

Asia Law (ed.) Intellectual Property Protection in Asia - Practical Strategies.

Baum, Harald (ed.) (1997) Japan: Economic Success and Legal System. Berlin: Walter de Gruyter.

Blakeney, Michael (1996) 'The Impact of the TRIPS Agreement in the Asia-Pacific Region,' EIPR, p. 544

Carter, Connie (1996) Fighting Fakes in China. London: Intellectual Property Institute.

Chang, Soo-Kil (1988) 'Trademark Prosecution Practice in South Korea,' IIC 19, p. 302.

Commission On Intellectual Property Rights In The 21st Century (1997) Towards the area of intellectual creation - challenges for breakthrough, Tokyo released on 7 April 1997.

Far Eastern Economic Review 'Are Asian Values Finished?' 22 January 1998, p. 32.

Far Eastern Economic Review, 'Pirates Kidnap Walt Disney,' 19 January 1995, p. 5.

Fei Country Report on the Judiciary and the IP System in China, WIPO ASEAN Regional Colloquium 1992, Geneva 1994 (WIPO Publication).

FTC homepage, http://www.jftc.go.jp.

Gao, Lulin (1995) 'Outstanding Achievements and Basic Experience Gained in the Decade Since the Implementation of the Chinese Patent Law,' Intellectual Property in Asia and the Pacific, January/March 1995, p. 15 (WIPO Publication).

Guo, Shuokan (1996) 'TRIPS and IP Protection in the PRC,' GRUR Int., p. 292.

Gutterman, Alan and Robert Brown (eds) (1997) Intellectual Property Laws of East Asia. Hong Kong/Singapore: Sweet \& Maxwell.

Heath, Christopher (1996) 'All Her Troubles Seemed So Far Away,' EIPR, p. 677.

- (1999) 'Industrial Property Protection in Vietnam,' IIC 30, p. 419.

Henderson, Dan Fenno (1997) 'The Role of Lawyers in Japan,' in: Harald Baum (ed.) Japan: Economic Success and Legal System. Berlin: Walter de Gruyter, p. 27.

Hoay, Tan Bok (1995) 'Protection of Intellectual Property in Singapore 1994 - A Survey,' EIPR, p. 163.

Hooker, M.B. (1988) The Laws of South-East Asia, Volume II: European Laws in South-East Asia. Singapore: Butterworths. 
Institute Of Intellectual Property (ed.) (1995) Asia shokoku ni okeru chiteki zaisan hogo (Intellectual Property Rights in Different Asian Countries). Tokyo (IIP Publication).

International Review Of Industrial Property And Copyright Law (IIC), 'Intellectual Property Rights in Asia,' June 1997, Vol. 28/3.

International Review Of Industrial Property And Copyright Law (IIC), 'Intellectual Property Rights in Asia II,' June 1999, Vol. 30/4.

lyori, Hiroshi and Uesugi, Akinori (1994) The Antimonopoly Laws and Policies of Japan. New York: Federal Legal Publishers.

Kaehlig, Carl-Bernd (1993) Indonesian Intellectual Property Rights. Jakarta: Tatanusa.

Kim, Byung-Il (1997) 'Unfair Competition Prevention in Korea,' IIC 28, p. 361.

-(1999) 'The Protection of Trade Secrets in Korea,' IIC 30, p. 403.

Konan et al. (1995) 'Intellectual Property Rights in the Asian-Pacific Region: Problems, Patterns and Policy,' Asian Pacific Economic Literature 11, pp. 9-2, 13.

Kono, Toshiyuki (1997) 'Judges and Mediators in Japan: The Administration as Motionless Mediator?' in: Harald Baum (ed.) Japan: Economic Success and Legal System. Berlin: Walter de Gruyter.

Kotani, Etsuji (1979) 'Takahashi Korekiyo kiden no koto (On the autobiography of Korekiyo Takahashi),' Patent 32, p. 71.

Ladas, Stephan (1930) International Protection of Intellectual Property. Cambridge, Mass: Harvard University Press.

- (1975) Patents, Trademarks and Related Rights. Cambridge, Mass.: Harvard University Press, 3 vols.

Legislation

- By-Law No. 117/1996 (26 December 1996).

- Copyright Act of 4 March 1899, Law No. 39.

- Law No. 116/1994.

- Law No. 14 of 27 March 1934.

- Shinkihatto No Ofuregaki (Ordinance Prohibiting Innovations), Ordinance of the Military Government of July 1721, reprinted in Tokkyo Chô (Patent Office) (1955) Tokkyo Seido 70 nen shi (70 Year History of the Patent System), Tokyo.

Leong, Susanna (1996) 'Salient Features of the Patent Act 1994 in Singapore,' IIC 27, p. 26.

Liu, Kung-Chung (1999) 'Unfair Competition Law in Taiwan,' IIC 30, p. 377.

McGrath, Michelle (1996) 'The Patent Provisions in TRIPS: Protecting Reasonable Remuneration for Services Rendered? Or the Latest Development in Western Colonialism?' EIPR, p. 398. 
Monya, Nobuo (1973) 'Zur Rezeption des deutschen Gebrauchsmusterschutzes in Japan,' Mitarbeiterfestschrift zum 70. Geburtstag von Eugen Ulmer, München.

Morikawa, Hidemasu (1992) Zaibatsu - The Rise and Fall of Family Enterprise Groups in Japan. Tokyo: University of Tokyo Press.

Nakagawa, Hiroshi (1984) Antimonopoly Legislation of Japan. Tokyo (FTC Publication).

Oddi, A.S. (1987) 'The International Patent System and Third World Development: Reality or Myth?' Duke Law Journal, p. 831.

- (1996) "TRIPS, Natural Rights and a "Polite Form of Economic Imperialism", Vanderbilt Journal of Transnational Law, p. 415.

Ooie, Shigeo (1981) Nippon chôsakuken monogatari (Tales on Japanese Copyright Law). Tokyo Shuppan Kaihatsu Sha.

Pun, K. H. (1995) 'Anti-Unfair Competition Law in China: Still Awaiting Supplements,' IIC 26, p. 637.

- (1997) 'Chinese Recent Development in Software Copyright,' IIC 28, p. 347.

Rahn, Guntram (1983) 'The Role of Industrial Property in Economic Development: The Japanese Experience,' IIC 14, pp. 449 (461).

- (1990) Rechtsdenken und Rechtsauffassung in Japan. München: C.H. Beck.

Rahn, Guntram and Christopher Heath (1994) 'What is Japanese about Japanese Unfair Competition Law,' IIC 25, pp. 343 (345).

Sakamoto, Kazuto Takahashi Korekiyo to tokkyo gyôsei (Korekiyo Takahashi and Patent Policy), Tokkyo Kenkyû 8 (Patent Studies), p. 34 [1989].

Someno, Yoshinobu (1959) 'Fusei kyôsô boshi hô (Unfair Competition Law),' Tokkyo Kanri 9, p. 18.

Tamai, Katsuya (1992) 'Mushinsa tokkyo toshite no saisei ka kanman na shi ka (Revival or Slow Death of Unexamined Patents?),' 1007 Jurist 63.

The Economist, 17 January 1998, p. 58.

The Economist, 22 January 1994, $62 / 63$ 'Intellectual Property is Theft.'

The Economist, 'Political Fall-Out in Indonesia,' 17 January 1998, p. 57.

The World Patent Survey (1996) Managing Intellectual Property 6, p. 19.

Tokkyo Chô (1955) Tokkyo seido 70 nen shi $(70$ Year History of the Patent System). Tokyo: Hatsumei Kyokai Publishing.

- (1985) Kôgyô shoyûken seido 100 nen shi (100 Years of History of the Industrial Property System), 3 vols., Tokyo: Hatsumei Kyokai Publishing.

- (1995) Kôgyô shoyûken seido kono 10 nen no ayumi (The Following 10 Years of Industrial Property System). Tokyo: Hatsumei Kyokai Publishing. 
INDUSTRIAL POLICY AND INTELLECTUAL PROPERTY IN JAPAN AND BEYOND

Tokkyo Kyoku (Patent Office), (1934) Tokkyo Kyoku 50 nen shi (50-Year History of the Patent Office). Tokyo: Hatsumei Kyokai Publishing.

Toyosaki, Joseph Koe, (1971) 'Unfair Competition in Japan,' IIC 2, pp. 372 (378).

Tsûsanshô (Ministry of Trade and lndustry) (1964) Shôkô seikaku shi (History of Trade and Industry), Tokyo, p. 558.

UCLA Pacific Basin Law Journal, Special Issue: Intellectual Property in East Asia, Fall 1994, Vol. 13/1.

Union Internationale pour la Protection de la Propriété Industrielle, Actes de la Conférence de la Haye, Den Haag 1925.

US Department Of Commerce/Patent Office (1972) The Story of the United States Patent Office. Washington DC.

Wineburg, Arthur (ed.) (1991) Intellectual Property Protection in Asia, Butterworth.

WIPO (1996) Background Reading Materials on IP Rights in Korea, Geneva (WIPO Publication).

Yang, Meongcho (1987) 'Anti-Trust Aspects of Technology Transfer to South Korea,' IIC 18, p. 371.

Yin, Xin-Tian (1991) 'A Patent Invalidation Case in China,' IIC 22, p. 513.

- (1993) 'The Newly Revised Chinese Patent Act - Brief Introduction,' IIC 24, p. 189.

Young, L.W. (1996) 'Taiwan and WTO Membership,' 1996/6 East Asian Executive Reports 9. 